\title{
IMPERIALISMO E GUERRA Civil No MUNDo ÁrABE: \\ A Tragédia SíRIa \\ PARTE I: A VIRADA ANTIINTERVENCIONISTA
}

Peter Demant

Resumo: Primeira de duas partes de artigo analisando a crise síria num contexto internacional e argumentando a favor de maior participação internacional pró-ativa na sua solução. Apesar de seu uso costumeiro entre partes da intelectualidade latinoamericana, o conceito imperialismo é pouco útil para entender as crises do Oriente Médio contemporâneo. Intervenções externas têm marcado a história recente da região, mas não todas tiveram caráter imperialista e/ou motivos econômicos. No pós-guerra fria houve tentativas para construir uma nova ordem internacional pautada por uma mudança das normas internacionais, e permitindo intervenções em caso de violações maciças dos direitos humanos da população e/ou risco de proliferação de ADMs. Um consenso intervencionista democrático "em vias de construção" foi quebrado pelos ataques islamistas de 11-9-2001 que provocaram a "guerra contra o terror" com intervenções lideradas pelos EUA no Afeganistão, Iraque e alhures. Estas tiveram seus resultados comprometidos por uma série de falhas tanto externas (relacionadas à legitimidade, inteligência, planejamento, soft power, e seletividade) quanto internas, produzindo eventualmente uma desmoralização nas democracias ocidentais, e nos EUA em particular, além da reviravolta anti-intervencionista que vigora atualmente. Esta reação continua apesar da perene importância global do Oriente Médio em termos estratégicos, econômicos e culturais. A nova tendência para uma certa retirada 
internacional tem determinado as mornas reações ocidentais e norte-americanas desde a eclosão da Primavera Árabe em 2011. A passividade das democracias ocidentais em apoiar a oposição anti-autoritária na Síria não só permitiu a sobrevivência do repressivo regime Ba`th, com apoio iraniano e russo, como também abriu uma janela de oportunidade para islamistas radicais.

Abstract: First of a two-part article that analyzes the Syrian crisis within an international context, and defends a more proactive international participation to resolve it. Despite its popularity among sectors of the Latin-American intelligentsia, the concept of imperialism is of little help in understanding current Middle Eastern crises. Although the region's recent history has been marked by foreign interventions, not all of those had an imperialist character or economic motive. The post-Cold War era was marked by attempts to build a new international order on the basis of new norms allowing intervention in cases of blatant violation of human rights and/or risk of WMD proliferation. The new democratic interventionist consensus that was in the making was, however, broken by the Islamist attacks of 9/11/2001. These led to American-led interventions in Afghanistan, Iraq and elsewhere, where a series of failures both external (related to issues of legitimacy, intelligence, postwar planning, soft power, and selectivity) and internal ended up undermining the results of the "war on terror". This eventually provoked demoralization in Western democracies and in the US in particular, and created an anti-interventionist backlash: the reaction continues until today despite the Middle East's unchanged global significance in strategic, economic, and cultural terms. The new tendency toward a certain international disengagement has dictated the West's lukewarm answers to the 2011 Arab Spring. In Syria reticence to support the anti-authoritarian opposition has not only allowed the repressive Ba'th regime to survive (with Russian and Iranian support) but also opened a window of opportunity to radical Islamists.

Falar de intervenções, sobretudo no Brasil, e da necessidade de uma intervenção EUA no Oriente Médio, é um exercício arriscado, que facilmente expõe o autor a acusações de imperialismo. A censura mútua e a autocensura não ocorrem por acaso. Os 
reflexos anti-estadunidenses da intelectualidade latinoamericana se explicam por uma história de invasões e violações. 0 continente tem sido objeto de múltiplas intervenções. Apos séculos de colonização e exploração por Espanha e Portugal a América do Sul sofreu, apos sua independência, intromissões britânicas e posteriormente, estadunidenses. Muitas destas intervenções foram motivados por interesses econômicos, ou para - sob a bandeira do anticomunismo - combater movimentos progressistas. Regimes militares pró-EUA foram culpados de graves violações aos direitos humanos. 0 automatismo antiimperialista é, portanto, compreensível.

Entender causas, no entanto, não equivale a uma justificativa eterna. Em particular quando a critica se torna tão automática que os críticos se alinham cegamente com qualquer Estado, regime ou grupo que se oponha aos EUA, ou ao ocidente em geral. Em nome da solidariedade contra o "imperialismo", intelectuais progressistas aplaudiram os abusos do regime soviético e chinês, cegos às torturas de populações inteiras: aconteceu entre a intelectualidade da esquerda na Europa nos anos 50 até 80; continua acontecendo aqui, no "último continente marxista". Mas, transportar o esquema imperialista da América Latina para o Oriente Médio traz mais inconvenientes do que ganhos. A crítica chega a absurdos. Assim uma certa esquerda critica, em nome da solidariedade com a suposta "frente de resistência" antiimperialista e antiisraelense formada por países tais como a Síria e o Irã e incorporando grupos como Hizbullah no Líbano e o Hamas na Palestina criticam os EUA por ter ajudado opositores ao regime de Bashar al-Assad ainda que minimamente. No Egito, os EUA são criticados por alguns por supostamente apoiar Muhammad Morsi, o presidente eleito da Irmandade Muçulmana, e por outros por não atuar contra o golpe militar que o desalojou. ${ }^{1}$ É claro que as condenações quase instintivas revelam mais sobre os preconceitos dos críticos do que sobre as crises que afligem o mundo muçulmano. A primeira precaução para evitar análises simplistas é de nos livrar de um antiamericanismo automático.

Neste texto analisarei a situação síria e chego à conclusão que a crise será insolúvel sem uma postura internacional muito mais pró-ativa da comunidade internacional em geral - e em particular da maior potência, os EUA. O conflito sírio tem se deteriorado tanto que uma intervenção externa se torna hoje conditio sine qua non pelo menos para evitar uma expansão regional da guerra civil. Não argumento que isto seja plausível na conjuntura atual, nem que terá necessariamente resultados positivos -

\footnotetext{
${ }^{1}$ Nos EUA, pelo contrário, Obama foi criticado por "permitir" que a Irmandade chegasse ao poder.
} 
apenas que é improvável o conflito chegar a uma solução minimamente justa sem uma participação internacional muito mais ativa em vários aspectos.

Sem dúvida uma ajuda anterior à oposição democrática síria, mesmo relativamente menor, poderia ter evitado a situação atual, talvez tornando supérflua a necessidade atual de um investimento de recursos humanos e estratégicos muito mais considerável. Esta hipótese nunca mais poderá ser testada. Agora, início de 2014, chegamos a uma conjuntura onde todas as alternativas parecem igualmente inaceitáveis: ou a restauração de uma ditadura minoritária cruel e ilegítima; ou o estabelecimento de um regime jihadista e expansionista; ou a continuação do derramamento de sangue e a destruição da sociedade síria. Mas, abandonar uma zona fundamental para a paz mundial à "guerra de todos contra todos", não é uma opção. Ela equivale a uma rendição ao desespero. Tanto da perspectiva "realista" das grandes potências quanto da mais "idealista", de uma comunidade internacional que a duras penas tenta se construir, seria uma posição moralmente covarde e politicamente suicida.

As responsabilidades pela exacerbação do conflito desde 2011 incluem muitos fatores, tanto internos quanto externos. A comunidade internacional não é isenta, ela é co-responsável pela tragédia atual, e deve (e ainda pode) assumir sua responsabilidade para ativamente introduzir os fundamentos de uma solução. Conceitos tais como "imperialismo" são de pouca ajuda para entender as raízes do problema e para desenvolver uma saída. Não se justifica condenar aleatoriamente qualquer intervenção como "imperialista" ("má") e ainda menos qualquer "negligência benigna" como progressista.

Para contextualizar estas afirmações, precisarei de um pequeno desvio, inclusive para mostrar que não podemos entender a crise síria atual a partir de um paradigma "imperialista". Veremos que, numa contrarreação às experiências no Afeganistão, Iraque e Líbia, a conjuntura atual nos EUA e em muitos outros Estados ocidentais se caracteriza, pelo contrário, por uma expressiva retração antiintervencionista e até isolacionista. A partir dessa limpeza intelectual, estaremos numa melhor posição para caracterizar a crise síria e dali formular os elementos de uma solução. 


\section{Imperialismo é um conceito útil para entender o mundo árabe hoje?}

Um rápido olhar sobre o conceito de imperialismo e a evolução de intervenções "imperialistas" no Oriente Médio destaca os limites de um conceito cuja utilidade na verdade se restringe à época pré-1914. É, de fato, no século 19 tardio e nas décadas antes da Primeira Guerra Mundial, período quando o capitalismo se expande e que um punhado de grandes potencias partilha entre si e coloniza a maior parte do planeta.

Teóricos marxistas como Lenin, Luxemburg, Hilferding, Bukharin, Kautsky, e Trotsky desenvolveram então a doutrina de que o capitalismo num estagio tardio de seu desenvolvimento, para resolver suas contradições internas e manter lucros suficientes precisa penetrar e explorar países ainda não integrados em sua orbita para sobreviver: a dinâmica interna do capitalismo tornaria assim imprescindível a "fase imperialista". ${ }^{2}$ De fato, em 1914, três quartos do mundo estava sob controle do "imperialismo": praticamente, apenas nove potências coloniais o partilhavam entre si: Grã-Bretanha, França, Holanda, Espanha, Portugal, Bélgica, Alemanha, Itália e Japão.

A análise de que a expansão do imperialismo - implementada através de inúmeras intervenções politicas e militares - respondeu a uma evolução econômica inevitável do capital, foi politicamente útil para direcionar os movimentos trabalhista e socialista, que se desenvolveram na mesma época ao redor do mundo industrial, à solidariedade com as resistências nacionalistas e anticoloniais que logo começaram a brotar na África e Ásia. Já que tanto os trabalhadores quanto os colonizados compartilhavam um interesse na derrota do capitalismo metropolitano, eles deveriam juntar suas forças. E assim aconteceu... eventualmente. ${ }^{3}$ Os movimentos anticoloniais adotaram programas progressistas, e os movimentos da esquerda no ocidente internalizaram os reflexos antiimperialistas que continuam até hoje, meio século após a

\footnotetext{
${ }^{2}$ A literatura relevante é vasta. Ver p.ex.: Ernest Mandel, Marxist economic theory. London: Merlin Press, 1974 (1962, 1st), pp. 441-484; Leszek Kolakowski, Main currents of Marxism vol. 2. The Golden Age. Oxford, etc.: Oxford UP, 1982. pp. 61-97 (R. Luxemburg), pp. 297-304 (R. Hilferding) e pp. 491-497 (Kautsky, Lenin, e Bukharin); op.cit, vol. 3. The breakdown pp. 183-219 (L. Trotsky); Stephen Hobden and Richard Wyn Jones, "Marxist theories in International Relations". In: John Baylis and Steve Smith, The Globalization of World Politics: An introduction to international relations. Oxford etc.: Oxford UP, 2001 (2nd. Ed.) pp. 200-223.

${ }^{3}$ De acordo com a teoria leninista era improvável a revolução proletária eclodir num país capitalista desenvolvido, já que os lucros imperialistas serviam e.o. para proporcionar salários mais elevados à "aristocracia trabalhadora". Isto tornou ainda mais importante a coordenação entre tendências revolucionárias trabalhistas em economias capitalistas menos desenvolvidas por um lado e tendências nacionalistas nas colônias por outro.
} 
descolonização. Mas, isto em si ainda não confirma o argumento de que hoje qualquer intervenção ocidental no mundo ex-colonial equivale a um ato imperialista".

Embora a teoria da necessidade econômica da expansão militar e política para que potências capitalistas conquistassem impérios, tivesse uma certa plausibilidade na época de ca. 1880 até 1914, durante o entreguerras e até a onda de descolonização pósSegunda Guerra, já então enfrentou problemas.

Muitas colônias, p.ex. na África, custaram mais à potência colonizadora do que renderam em termos econômicos; outras foram colonizadas por motivos demográficos ou de prestigio, ou ainda preventivamente para evitar sua captação por uma outra potencia. Finalmente, houve muitos Estados capitalistas que não participaram na corrida colonial (p.ex. os países escandinavos, a Dupla Monarquia austro-húngaro, Suiça, e por muito tempo, os próprios EUA). No mesmo tempo um outro pais dos mais expansionistas, a Rússia, era primitivo demais para ser considerado plenamente capitalista. 4

Leituras mais recentes tampouco conseguiram salvar o conceito imperialismo como teoria para explicar o desenvolvimento global político e econômico. Apesar de novas teorizações sobre "neocolonialismo", dependência e sistemas-mundo (Frank, Wallerstein, Cardoso... $)^{5}$ com o colapso dos impérios e a onda de independências após 1945, o conceito de imperialismo passou a ser ainda menos funcional. Contra as previsões, os países capitalistas desenvolvidos se adaptaram à perda de suas colônias e sobreviveram bem sem produtos e mercados coloniais. 0 comercio e a exportação de capitais entre as economias capitalistas desenvolvidas logo ultrapassou aquele entre o primeiro e o terceiro mundo. Neste, após várias tentativas para se descolar do mercado mundial, além de experimentos autárquicos catastróficos, a maioria dos Estados acabou se curvando e buscando os investimentos estrangeiros. Ou seja, viabilizou-se um capitalismo independente de imperialismos.

A descolonização coincidiu amplamente com a Guerra Fria (1945-1990). A luta bipolar que englobou quase toda a humanidade levou ambos os protagonistas a fazer alianças com (ou instalar) regimes identificados com sua postura ideológica - mesmo se estes regimes tratavam seus súditos de modo hediondo: os chamados "tiranos

\footnotetext{
${ }^{4}$ Wolfgang J. Mommsen, Imperialismustheorien. Göttingen: Vandenhoeck \& Ruprecht, 1977.

${ }^{5}$ Immanuel Wallerstein, The Modern World-System. San Diego: Academic Press, 1974 (3 vols.); Andre Gunder Frank The Development of Underdevelopment (1966) e muitas outras obras.
} 
amistosos". A URSS dominou seu bloco, e os EUA forjaram alianças anticomunistas com regimes ditatoriais e repressivos. Só quando estas alianças não deram certo, foram iniciadas intervenções militares. Após séculos de colonização e décadas de guerras mundiais destruidoras e genocidas, o ocidente perdera muito de sua soberba ideológica, e as críticas foram silenciadas com o argumento que o ditador (qualquer quem fosse ele) pelo menos mantinha a paz interna, e que seu desaparecimento desencadearia uma guerra civil.

A mesma justificativa se usada hoje para legitimar a ditadura de Assad na Síria. $\mathrm{Na}$ ótica do relativismo cultural que vigorou após a Segunda Guerra, crimes cometidos por tiranos da mesma nação pareciam de algum modo menos vis, e o autocrata que massacra seu próprio povo mantém uma legitimidade maior do que eventuais invasores externos.

A dinâmica do embate capitalista-comunista provocou inúmeras guerras por proxy ("guerra por procuração") e outros tipos de intromissão tanto por parte dos EUA quanto da URSS e seus respectivos satélites. A guerra fria explica o porque da maioria das muitas intervenções de potencias capitalistas em países do terceiro mundo. Às vezes as causas eram realmente econômicas. Um caso infame foi o golpe em 1954 contra Mossadeq que nacionalizara o petróleo iraniano, maquinado pela CIA. Houve também intervenções onde elementos econômicos se mesclavam com outros. Porém, na maioria dos casos, preocupações com a "estabilidade política" e considerações estratégicas, em particular anti-soviéticas e anticomunistas (às vezes baseadas em medos irreais, como no caso do Brasil em 1964), pesaram mais do que considerações econômicas. Atribuir a responsabilidade ao "imperialismo" ou a entidades nebulosas conspiratórias afins é, no entanto, uma grosseira simplificação. De fato, uma vez liquidada a competição com a URSS, as novas intervenções lideradas por potencias ocidentais logo mudaram de natureza.

\section{0-2001: 0 auge do intervencionismo multilateral}

O desaparecimento do império soviético, com o consequente fim da bipolaridade e da guerra fria, levaram a uma diminuição da rivalidade com a Rússia e a um 
perceptível declínio das intervenções. Intervenções imperialistas de tipo "clássico" têm se tornado ainda mais raras. Não significa que os EUA cessaram de proteger seus interesses inclusive por meio de intromissões externas; todos os Estados o fazem, embora nem todos disponham dos mesmos recursos. Mas, interesses propriamente capitalistas, leia-se, a pressão política de empresas, poder financeiro..., hoje são impostos de forma mais indireta ou consequentemente não conseguem mais ditar as políticas externas dos Estados. Durante a década de 90, no entanto, embora a época do governo Clinton fosse repleta de intervenções, essas tinham mudado de natureza. ${ }^{6}$ A agenda internacional estadunidense foi ditada cada vez mais por motivos mais benignos e mais condizentes com a nova ordem internacional liberal que eles doravante pretendiam fazer avançar: cooperação securitária, expansão da prosperidade levada pela globalização, proliferação da democratização... Além do mais, num contexto internacional menos ameaçador, também o apoio doméstico para intervenções estrangeiras se restringiu. Ao custo econômico de aventuras militares (e da frustração com os aliados europeus que deixaram os EUA carregar sozinhos "O Fardo do Homem Branco") se adicionou um custo político cada vez mais elevado, pois um papel internacional ativo já não era popular com a direita isolacionista nem com a esquerda antiimperialista. Ou seja os primórdios da atual tendência estadunidense de retirada internacional se encontram já naquela época pós guerra fria. Também outras potencias seguiram, às vezes com certo atraso, esta tendência. Alemanha e Japão mantiveram, desde sua catastrófica derrota na Segunda Guerra, um baixo perfil internacional e uma postura pacifista. Mas também as duas principais potencias coloniais vencedoras da Segunda Guerra, a Grã-Bretanha e a França se acomodaram com a perda de seu império. Desde os anos 70 e ainda mais desde os 90, suas aventuras externas são poucas e esporádicas (Malvinas, África...). Intervenções externas progressivamente se transformaram em instrumento de manutenção dos direitos humanos e da segurança internacional.

Paradoxalmente a única potência remanescente que sistematicamente continuou práticas "imperialistas" foi a URSS, não-capitalista. A Rússia pós-comunista e mais conservadora de hoje, embora uma sombra de seu predecessor soviético, segue

\footnotetext{
6 Os destaques da política externa do governo Bill Clinton incluem intervenções na Somália em 1992, Bósnia 1993, Haiti 1994, Kosovo 1999; ataques contra as defesas iraquianas em 1993 e 1996 em reação a supostas provocações de Saddam Hussein; ataques em 1998 contra interesses de al-Qaeda no Afeganistão e no Sudão; além de uma ativíssima diplomacia no quesito Israel-Palestina.
} 
amplamente a mesma política externa. Apesar de seu imenso território, sente-se ameaçada e tenta recuperar a antiga esfera de influência soviética no "Próximo Exterior": Ucrânia, o Cáucaso, Ásia Central.... Ao lado dos determinantes geoestratégicos, há ainda a evolução interna russa, onde o fracasso do projeto democrático e o fortalecimento de tendências autocráticos ditam sua resistência a intervenções externas. A relação russa com a Síria, tanto como ponto de apoio da influência militar russa quanto como mascote diplomático, obedece a esta lógica.

Se, com exceção da Rússia , a época pós-guerra fria testemunhou um retrocesso de intervenções militares unilaterais ditadas por motivos econômicos ou estratégicos, por outro lado houve uma recrudescimento de intervenções "estabilizadoras" (mormente multilaterais, e muitas vezes legitimada pela ONU) para frear agressões transfronteiriças (p.ex. em 1991 contra a conquista e anexação de Kuwait pelo Iraque), ou para conter crises humanitárias, em particular em casos onde "Estados falidos" exibem incapacidade de lidar com situações que tem risco de transbordar (p.ex. na Somália em 1992), ou ainda para frear genocídios ou outras grosseiras violações de direitos humanos (p.ex. Kosovo 1999). 0 pano de fundo deste novo tipo de intervenção era a emergência de esperanças idealistas de que uma nova ordem internacional mais justa iria se estabelecer na coexistência de Estados que, embora soberanos, concordariam em condicionar sua soberania no respeito aos direitos humanos de suas (e outras) populações. Caso contrário, a nova teoria - numa significativa nova elaboração da lei internacional que restringe o sacrossanto principio da não-intervenção nos afazeres internos - legitimaria uma intervenção pela "responsabilidade de proteger". Embora não exatamente aplaudida por potencias tais como a Rússia, a China, Irã, Cuba, Coreia do Norte, Mianmar, Zimbabwe, Venezuela - e com ressalvas significativas também de emergentes como a Índia e o Brasil - à época essa postura parecia ir de vento em popa: um movimento em direção a um mundo mais seguro e onde a ONU, autoproclamada representante de toda a humanidade, se arrogou progressivamente mais poderes para intervir contra governos que não obedecessem a uma norma mínima de comportamento humano. 
É no período pós-guerra fria que, pela primeira vez desde a criação da ONU, os dois cenários que justificam intervenções foram postos em prática, pelo menos em certos casos: a proteção dos direitos humanos e a prevenção da proliferação de ADMs. ${ }^{7}$

1. Violação maciça de direitos humanos: Desde a Segunda Guerra Mundial e o descobrimento dos horrores do Holocausto contra judeus e outros grupos contemplados para o extermínio, a comunidade internacional considera inaceitável o genocídio de grupos humanos. A ONU, originalmente United Nations Against Fascism, se pauta numa ideologia que não somente pretende evitar novas guerras internacionais como também estimular a responsabilidade da comunidade internacional para o bem-estar dos seres humanos. A Declaração Universal dos Direitos Humanos, carro-chefe deste ideal, foi elaborada sob a sombra dos 50 milhões de mortos da Segunda Guerra. ${ }^{8}$ Desde os processos de Nuremberg em 1946, a culpa por massacres e genocídio não pesa só nos ombros dos perpetradores mas também nos dos que sabiam mas se calaram. Hoje todos sabemos. Ignorar não é apenas vergonhoso - também abaixa o limiar para o próximo assassinato em massa e portanto, aproxima a próxima crise humanitária. Em consequência, uma solidariedade ativa com seres humanos numa crise, mesmo longínqua, não é apenas uma expressão moral de nossa humanidade. É também, em última instancia, nosso próprio interesse.

2. Proliferação de Armas de Destruição em Massa: As ADMs são por definição armas anti-civis e portanto, profundamente imorais pelas leis da guerra. Não são apenas armas com o potencial de eliminar a vida humana no planeta. Elas servem também como escudo de chantagem, tornando praticamente invulneráveis regimes hediondos, pois inviabilizam qualquer diálogo, mesmo em casos de maciça violação de direitos humanos. ADMs tornam os detentores não apenas

\footnotetext{
${ }^{7}$ Houve casos de intervenção humanitária sob auspícios da ONU anteriores ao fim da Guerra fria, p.ex. na crise de Congo, na Guerra civil angolana, em Chipre, Líbano e no conflito israelo-árabe. Contudo tratou-se de poucos casos, e devido às diferenças dentro de Conselho de Segurança, as intervenções foram em geral não-impositivas e/ou de observadores monitorando acordos de cessar-fogo já concordados.

${ }^{8}$ A origem da Declaração Universal do Direitos Humanos de 1947 está no discurso das Quatro Liberdades do presidente Franklin D. Roosevelt na sua declaração State of the Union de 1941: ter liberdade de expressão (Freedom of speech), de religião (freedom of worship), e estar livre de carência (freedom from want) e de medo (freedom from fear). Estas duas últimas liberdades iriam evoluir para, respectivamente, o direito ao desenvolvimento sócio-econômico ou seja a um padrão de vida humanamente adequada; e o direito à "segurança humana" incluindo a proteção contra guerra, agressão e totalitarismo, e a concomitante necessidade de desarmamento. As quatro liberdades foram retomadas na Carta Atlântica de 1941, aceitas por todas as nações aliadas e eventualmente elaboradas na DUDH.
} 
invulneráveis mas também globalmente perigosos caso optassem por políticas agressivas.

A posteriori é possível criticar esta esperança como ingênua demais. Interpretar as intervenções pós-guerra fria como apenas mais um avatar do capitalismo tardio, no entanto, parece altamente artificial. Os intelectuais da esquerda da época tiveram, de fato, crescente dificuldade para encaixar intervenções contra ditadores hediondos e/ou para aliviar crises humanitárias.

\section{1-2010: 0 9/11 e as consequências: a "guerra contra o terror" islamista radical quebra o consenso intervencionista democrático}

O que quebrou a dinâmica global em direção de uma nova coexistência mais pacífica, e expôs a fragilidade do novo consenso internacional que se basearia em normas democráticas e de direitos humanos, foi o ataque de al-Qaeda de 9/11 contra alvos nos EUA em 2001. O choque foi tão extremo que também produziu novas reações extremas - e extremamente opostas - nos EUA por um lado, e por outro no mundo nãoocidental, muçulmano em particular. Os demais públicos ocidentais flutuam entre os dois desde então.

Ainda sob o choque do 9/11, o governo norte-americano de George Bush imediatamente definiu os ataques terroristas como ato de guerra, embora sem que o agressor fosse um Estado ou mesmo pudesse ser nitidamente identificado. A parte agredida reagiu com hostilidades que na auto-percepção equivaliam a uma guerra defensiva contra os agressores e seus supostos protetores. De 2001 até a ascensão de Obama em janeiro de 2009, os EUA e alguns aliados responderem com a "guerra contra o terror" e lançaram novas intervenções, contra al-Qaeda, Afeganistão, Iraque, e outros alvos. ${ }^{9}$ Em outubro de 2001 os EUA aplicaram sua nova estratégia contra o Afeganistão, desalojando o regime talebã que abrigara Osama bin Laden, e abrindo o país para o experimento democrático. Em março de 2003, atacaram o Iraque sob alegações de que este produzia ADMs, e desalojaram o regime Ba`th de Saddam Hussein. Também ali a ideia de facilitar um processo de democratização se sobrepôs à racional inicialmente

\footnotetext{
${ }^{9}$ A definição de terrorismo e sua relação com guerra e "leis da guerra" está fora do escopo deste artigo.
} 


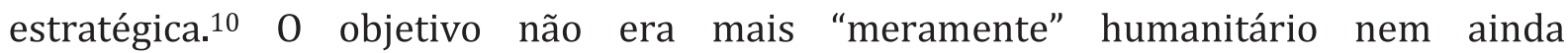
pontualmente militar, embora com o decorrer do tempo o medo da proliferação de ADMs por "regimes vilões" como a Coréia do Norte, o Irã e o Iraque, e o risco delas caírem nas mãos de terroristas, se tornasse um fator bastante significativo. Na verdade, o programa articulado por intelectuais neoconservadores e intervencionistas liberais foi bem além, chamando pela expansão da democracia mediante mudanças de regime. Havia no fundo a esperança de que a universalização da autodeterminação ajudaria as sociedades médio-orientais (e muçulmanas em geral), presas numa dolorosa transição, a se modernizarem. A modernização expandiria as oportunidades econômicas e ampliaria as escolhas de estilo de vida. Com isto a atração do terrorismo de cunho islamista diminuiria, desta maneira melhorando a segurança dos EUA. Como também se acreditava que democracias tendiam a manter relações pacificas entre si, o resultado seria bom para a segurança de todos. ${ }^{11}$

Em outras palavras, os EUA reagiram com reações militares não só contra os perpetradores diretos, mas também contra regimes antidemocráticos culpados indiretamente por supostamente "fazer brotar" terrorismos islamistas: tal foi a lógica subjacente da "guerra contra o terror", iniciada sob os auspícios do governo de G. Bush Jr.

Em ambos os casos, Afeganistão e Iraque, um tênue começo de democratização e de implantação do império da lei e do respeito aos direitos humanos ocorreu, com um certo progresso para grupos vulneráveis como mulheres e minorias étnicas e religiosas.

Mas, em ambos os países as complicações decorrentes de uma longa ocupação estrangeira logo iriam solapar a popularidade do programa intervencionista neocon. Tensões e violências comunitárias cresceram, com vários grupos atacando e matando

10 É útil lembrar que nos quatro casos onde a questão da proliferação das ADMs entrou no debate intervencionista, o cenário de seu uso não foi imaginário:

a) Afeganistão 2001: al-Qaeda buscou e continua buscando ativamente ADMs e promete usá-las contra civis para implementar seu programa islamista universal;

b) Iraque 2003: Saddam Hussein incorporou um programa pan-árabe "bismarckiano", ativamente buscou armas nucleares, foi um agressor serial (Irã 1979, Kuweit 1990 etc.) e comprovadamente usou armas químicas tanto contra as forças iranianas quanto contra civis curdos nos anos 80 . 0 fato de que em 2003 não possuía as ADMs que Bush alegara não eliminou o risco potencial uma vez que o Iraque proibiu inspeções criveis;

c) o Irã tem uma liderança pelo menos parcialmente comprometida com um expansionismo xiita milenarista e abertamente ameaçou varrer do mapa ao menos um Estado (Israel);

d) a Coréia do Norte é um Estado falido e faminto com um regime louco e mortífero que pressiona os EUA com ameaças de ataques nucleares.

${ }^{11}$ A racional é retomada de forma mais sofisticada em por Philip Bobbitt, Terror and consent: The wars for the twenty-first century. New York: Albert A. Knopf, 2008. 
soldados norte-americanos e ocidentais. A guerra contra o terror custou milhares de soldados e bilhões de dólares. Quando as forças opostas à "democratização induzida" provaram mais força do que o previsto, o entusiasmo no eleitorado EUA diminuiu e a base política para esta empreitada evaporou.

Por que estas fracassaram tão espetacularmente? Antes de detalhar como a Primavera Árabe a partir de 2011 se entrelaçou com a crise do intervencionismo, é preciso explicar rapidamente as causas do descompasso das intervenções. Podemos apontar seis erros cruciais - todos influenciando os debates sobre a Síria agora: as intervenções foram vistas como (1) ilegítimas, (2) baseadas em informações incorretas quanto às ADMs de Saddam Hussein, (3) iniciadas para derrotar um regime mas sem preparo adequado para substitui-lo (por nation building) e (4) sem propaganda adequada para justificá-las ao olhar árabe, além de (5) focar certos regimes particularmente odiados (o "eixo do mal") negligenciando outros não menos condenáveis e (6) se vulnerabilizar no olhar público ocidental à falta dos resultados estruturais rápidos, e a acusações de imoralidade pelos novos "condenados da terra" os islamistas e seus defensores na intelectualidade ocidental.

1. Legitimidade comprometida: três das cinco potencias com direito a veto se opuseram à invasão do Iraque em 2003 (mais tarde, duas dentre elas, a Rússia e a China, vetariam repetidamente posturas mais firmes frente à Síria, em 2012 e 2013). É razoável esperar uma resistência à aplicação dos princípios que tendam a solapar a primazia da não-intromissão, por parte de potencias que temem se tornar o próximo objeto de uma tal intervenção. Em outras palavras, até que Rússia e China se transformem, sua oposição a decisões de interferência é quase axiomática. Este é um obstáculo que Estados a favor de intervenção não podem evitar. Dali as tentativas para gerar uma legitimidade alternativa, através de outras instituições ou agrupamentos, da OTAN à (patética) "coalizão dos voluntários" e à nunca realizada fantasia de uma ONU paralela de democracias. Em última instancia, em casos onde a moralidade dita uma postura ativa e a lei a proíbe, não haverá como escapar do dilema, e os estadistas deverão fazer sua escolha entre o imoral ou o ilegal.

2. Inteligência questionável: A primeira justificativa para a invasão do Iraque baseou-se na suposta presença de ADMs. A posteriori o argumento pareceu se sustentar numa informação falsa e/ou manipulada da inteligência, o que nutriu 
acusações de uma mentira premeditada. Este fracasso influenciou a decisão sobre a Síria. ${ }^{12}$

3. Falta de planejamento, pessoal e recursos: As invasões foram feitas com forças e despesas materiais mínimas. 0 numero insuficiente de soldados, e pior, um planejamento inadequado para "day after" além da ausência de um programa de engenharia social para a "construção de uma nação", adequadamente tripulado e financiado, permitiu a criação de rebeliões por nostálgicos do ancien régime e jihadistas. A repressão destas se encaixou perfeitamente no imaginário popular do imperialismo yankee...

4. Falta de construção de soft power: Os proponentes das intervenções parecem ter acreditado que o antiocidentalismo era um efeito superficial da propaganda dos regimes que iriam substituir mas esse antiocidentalismo está enraizado no Oriente Médio como consequência de um milênio de antagonismo cristãomuçulmano e de tentativas (estas, verdadeiras!) imperialistas para colonizar e explorar o mundo árabe. Esta ingênua visão completamente subestimou a profundeza dos traumas mentais existentes, as memórias de invasões passadas, o sentimento de dignidade ferida, a reserva de fanatismo religioso, e outros fatores psicológicos que opositores das intervenções exploraram. Consequentemente, não fizeram esforços suficientes para construir uma imagem mais positiva.

5. Seletividade interesseira: é comum a acusação de hipocrisia nas críticas a qualquer intervenção. Porque os EUA intervieram no Iraque e não contra um aliado protegido como Israel? Porque punem o Irã ou Egito e não o Barein? Porque Israel (e os próprios EUA) tem direito a ADMs mas o Irã não? Se há intervenção "humanitária" no Iraque mas não em Ruanda, isto não comprova que os interventores agem por motivos econômicos ao invés de humanitários? Este tipo de argumento é obviamente trigo para o moinho dos teóricos da conspiração que sempre buscam "desvendar" agendas sinistras escondidos. Na realidade, obviamente os recursos disponíveis (dinheiro, energia, tempo, informação...) são sempre finitos e o número de casos que merecem maior e mais atenção e investimento desses recursos, sempre ultrapassa estes limites. Além do mais,

12 Cf. porém as violações por Iraque de programas desenvolvimento de ADMs proibidos pela ONU, no Comprehensive Report of the Special Advisor to the DCI on Iraq's WMD ("relatório Duelfer") do Iraq Survey Group de 2004: http://www.gpo.gov/fdsys/search/pagedetails.action?granuleId=\&packageId=GPODUELFERREPORT\&fromBrowse=true 
mesmo Estados comprometidos com um ideário humanitário, liberal e democrático, dificilmente agiriam frontalmente contra seus interesses estratégicos vitais. Em geral é razoável admitir que uma correspondência entre necessidade local e interesse do interventor em potencial constitui um fator que aumenta a probabilidade de intervenção (o que ajuda explicar porque a possibilidade de massacre de talvez milhares em Benghazi, Líbia, provocou uma intervenção; e a atualidade do genocídio de centenas de milhares no Darfur sudanês, não). Alguma seletividade é, então, inevitável. No entanto, quando a suspeita de interesses se torna uma carta propagandística que impede o apoio político necessário para o êxito de uma intervenção que de resto seria desejável ou necessária - então é mister endereçar e neutralizar a crítica.

6. Desmoralização doméstica: Ao lado destes cinco fatores externos ocorre também um enfraquecimento interno fatal da vontade coletiva estadunidense para aplicar a força necessária - e por tanto tempo quanto necessário - para obter e consolidar os objetivos anunciados. Autores próximos dos neocons tais como Niall Ferguson e Robert Kagan têm criticado a "falta de paciência" com resultados duradouros, e a "intolerância" da opinião pública estadunidense a baixas militares e civis. Tal hipersensibilidade ao que eles veem como preço inevitável cobrado por cada empreendimento militar, que a sociedade paga para se proteger e/ou para estabelecer um império, ameaçaria de antemão o êxito das intervenções de Bush. ${ }^{13}$

Argumento culturalista insuficiente. A realidade é obviamente bem mais complexa. A crescente sensibilidade a perdas de guerra não é única para os EUA mas se observa em todas as sociedades democráticas "pós-modernas" (até em sociedades fortemente militarizadas como Israel): de acordo com autores tais como Anthony Giddens e Ronald Inglehart, essa crescente empatia e "humanização" refletem, quando sociedades se tornam mais seguras e prósperas, uma transição universal de valores de

\footnotetext{
13 Niall Ferguson, Colossus: The Price of America's Empire. Penguin, 2004. Para Ferguson a impaciência norte-americana se compararia negativamente com a suposta resiliência dos imperialistas britânicos de outrora; Robert Kagan, Of Paradise and Power: America and Europe in the New World Order. New York: Vintage, 2004. Cf. também Victor Davis Hanson, Carnage and Culture: Landmark battle sin the rise of western power. New York: Anchor, 2001.
} 
"sobrevivência" para "pós-materialismo".14 Mas, o fator determinante parece ser menos a cultura ou a mentalidade do público norte-americano, do que sua convicção na justiça e inevitabilidade da guerra. Não houve "intolerância" aos 400.000 mortos estadunidenses na Segunda Guerra Mundial, apesar do forte isolacionismo que a precedeu. E a Guerra Civil de 1860-65, muitas vezes mais cara em termos de perdas humanas, continuou até o amargo fim. No início, a Guerra contra o Terror foi altamente popular, determinando a reeleição de Bush em 2004. 0 desgaste veio paulatinamente, pela combinação de dois erros domésticos cruciais: com o passar do tempo o objetivo proposto, a transformação democratizante e modernizadora da sociedade invadida, não só parecia muito mais difícil e caro de se alcançar do que o esperado, mas também progressivamente menos moral. Graças à ampla disseminação dos erros e crimes ocidentais (p.ex. em Abu Ghraib) e ao paradigma do relativismo cultural, predominante na intelectualidade norte-americana e sagazmente explorado por propagandistas islamistas (absolutamente não relativistas!), criou-se-se uma virada ideológica. A crítica às intervenções deixou um rastro de desmoralização e no imaginário popular se mesclou com outros males sociais. Mais do que a crítica de fora e mesmo do custo econômico das ocupações, a erosão da crença popular na justiça da própria causa foi a causa fundamental da virada para o anti intervencionismo atual.

Como se vê, os problemas misturaram fatores internos aos EUA, internacionais, e específicos ao mundo muçulmano, e a maneira como esse "processou" mentalmente o 9/11. Na verdade, mundo afora, o 9/11 causou, na maioria dos Estados - após o imediato choque solidário com as vitimas nas Torres Gêmeas - tergiversações e desconforto com as reações estadunidenses consideradas belicistas e interesseiras. Islamistas radicais, inicialmente grupos marginais rejeitados pela maioria dos muçulmanos, foram dos poucos cujas certezas se mantinham: reagiram com avisos de novos ataques terroristas contra uma grande diversidade de alvos. Estes logo se verificaram e nunca mais pararam, ainda que não alcançassem as dimensões do 9/11.15

\footnotetext{
${ }^{14}$ Anthony GIDDENS, The consequences of modernity. Stanford, CA: Stanford University Press, 1990; para o pensamento de Ronald Inglehart, cf. http://www.worldvaluessurvey.org

15 Para mencionar apenas os ataques jihadistas mais importantes desde 11-9-2001 cometidos fora do mundo muçulmano (onde eles têm sido em Iraque, Paquistão e Afeganistão): em 2001 em Israel (Jerusalém, restaurante Sbarro, e Tel-Aviv); em 2002 na Indonésia (Bali), as Filipinas (Zamboanga) e Israel (Haifa, restaurante Matza; Netanya; Jerusalém (Café Moment) e paradas ônibus Patt Junction e Karkur Junction) e Rússia (Grozny, Chechênia; em 2003 em Israel (Haifa ônibus 37 e ônibus Shmuel HaNavi) e Rússia (Praça Vermelha, Moscou, Znamenskoye e Stavropol; em 2004 na Espanha (Madri), as Filipinas, e Rússia (Moscou e Beslan em Ossétia Setentrional; em 2005 no Reino Unido (Londres) e na
} 
Esses novos ataques jihadistas causaram, como devem ter calculado seus organizadores, uma intensificação da guerra contra o terror: esta inevitavelmente vitimou também inocentes. Em decorrência dos erros cometidos em nome da reação ocidental, alimenta-se no mundo muçulmano em geral e no Oriente Médio em particular, um antiocidentalismo cada vez mais expressivo: trata-se de uma rejeição não apenas ao poder político, econômico e militar das potencias ocidentais mas também de seus valores culturais - incluindo, de forma sinistra, uma recusa à universalidade dos direitos humanos. De um dia para o outro, a modernidade democrática e capitalista, centrada nos EUA, mas global em sua promessa universal para toda a humanidade, se viu desafiada por uma força antiocidental e antidemocrática ainda difusa, mas com ecos que se ampliariam nos próximos anos.

Conclusão: apesar de alguns resultados que temporariamente podiam parecer positivos, a maneira como foi aplicada a estratégia fomentou, no prazo de uma década, resultados opostos aos pretendidos - e desastrosos para os EUA e seus aliados. 0 efeito bumerangue não-intencional das intervenções ocidentais, continua até hoje. A guerra contra o terror não conseguiu deslegitimar o islamismo radical; amplamente fracassou em pacificar e democratizar os Estados-alvo das intervenções; alimentou uma onda popular anti-EUA e antiocidental e no próprio ocidente acabou nutrindo desapontamento, isolacionismo e uma reação anti intervencionista por puro cansaço e desesperança. A atmosfera atual de desmoralização e de confusão intelectual que permeia não apenas os EUA mas o ocidente em geral, remete imediatamente às desavenças das intervenções pós-9/11.16

Índia (Déli); em 2006 nas Filipinas (Mindanao), Índia (trem em Mumbai e Varanasi) e Rússia (mercado em Moscou ); em 2007 na Índia (no Samjhauta Express, e em Hyderabad); em 2008 na Índia (em Mumbai, Jaipur e Déli), Rússia (num ônibus em Vladikavkaz, em Ossétia Setentrional) e em Israel (Jerusalém, yeshivat Merkaz ha-Rav); em 2009, nos EUA (Fort Hood, Texas), na Rússia (no trem Nevsky Express entre Moscou e São-Petersburgo, e em Nazran, Ingushetia); em 2010 na Rússia (metrô de Moscou e em Stavropol; em Vladikavkaz; em Kizlyar no Daguestão; e no parlamento de Grozny em Chechênia; na Índia (Mumbai e Pune) e Uganda (Kampala); em 2011 em Kashgar e Hotan no Xinjiang chinês, na Rússia (aeroporto de Domedododvo, e em Belarus (Minsk); em 2012 na França (Toulouse); e em 2013 na maratona de Boston (EUA), em Woolwich Londres, e em Nairobi, Quênia.

No mesmo período houve inúmeros ataques islamistas contra outros muçulmanos (somando muito mais vítimas), particularmente frequentes e mortíferos no Iraque, Afeganistão, e Paquistão, mas também acontecendo em Marrocos, Líbano, Jordânia, Arábia Saudita, Indonésia, Somália, Nigéria, Bangladesh e alhures...

Cf. Wikipedia, "List of battles and other violent events by death toll":

http://en.wikipedia.org/wiki/List_of_battles_and_other_violent_events_by_death_toll\#Terrorist_attacks 16 Obviamente entraram também em jogo outros fatores, p.ex. os efeitos da crise financeira de 2008 e o consequente aumento do desemprego. 


\section{1-hoje: da Primavera Árabe ao atual clima antiintervencionista}

Tal foi o quadro desanimador quando nos últimos dias de 2010 eclodiu na Tunísia a onda democratizadora que logo arrastaria a região inteira na "Primavera Árabe". Mas quando finalmente as massas árabes se levantaram contra seus ditadores e logo precisaram de ajuda contra os tanques, aviões e bombas destes últimos - a atmosfera no ocidente já se transformara em ostensiva não- intervenção.

O fracasso da ideologia intervencionista foi seguido pelo fracasso não menos retumbante da política oposta, cautelosa e de intervenção mínima, posta em prática por Obama, que ao decorrer de sua presidência enfatizou cada vez mais sua preferência anti intervencionista. Quando em 2009 a população do Irã se revoltou contra o regime teocrático, o governo estadunidense não fez nada. Em 2011 as tropas dos EUA se retiraram do Iraque, e em 2014 a retirada do Afeganistão deve se completar. Os EUA abandonam duas sociedades traumatizadas por anos de guerra civil, com instituições democráticas inacabadas, países que não conseguiram afinal realizar uma pacificação entre suas comunidades, inclusive com retrocessos na segurança e nos direitos de suas populações. A única coisa que doravante une os atores políticos é a rejeição aos EUA, que estão perdendo qualquer vestígio de prestigio sobre estes Estados.

No entanto, o apoio norte-americano à Primavera Árabe se mantém num patamar de invisibilidade máxima. Na Líbia, os EUA apoiaram em 2011 uma intervenção aérea limitada que conseguiu quebrar o ditador Qadhafi mas, esconderam-se por trás de aliados europeus. Por outro lado (e exceto o caso líbio que ameaçou afetar diretamente Itália, França e outros países europeus), os aliados ocidentais dos EUA não ousam se aventurar muito sem o apoio dos EUA. 0 assassinato de bin Laden em território soberano paquistanês inflamou os ânimos islamistas e nacionalistas, na talvez mais instável sociedade nuclearizada do mundo.

No Egito, o apoio estadunidense morno ao ditador Mubarak se alternou com um apoio não menos vacilante a seu sucessor, o democraticamente eleito presidente Morsi em 2012. Em 2013 houve uma condenação morna ao golpe militar mubarakista, que está restabelecendo a ditadura militar sob uma máscara "constitucional”.

Em nenhum país árabe a bancarrota geopolítica e moral do ocidente, e da comunidade internacional, é mais gritante do que na Síria, que detalharemos na Parte II 
deste artigo. ${ }^{17}$ Aqui, os EUA destruíram as pontes com o ditador Assad mas, falharam em apoiar os opositores democráticos, deixando jihadistas sunitas tão violentos e cruéis quanto o ditador atacar a resistência popular. Ou seja, nada fizeram de concreto mas esse apoio morno talvez tenha mesmo colocado lenha na fogueira do antiocidentalismo. Pois mesmo ausente, o fantasma do "intervencionismo" norte-americano continua nutrindo teorias conspiratórias e destrói os últimos vestígios de simpatia no Egito; na Arábia Saudita essa política é lida como passividade e também provoca uma crise de confiança com os EUA. Em comparação a todas estas desventuras, o glacial impasse nas negociações israelo-palestinas parece quase um alivio.

Nem tudo é culpa de Bush ou Obama. Nenhuma campanha poderia ter desenraizado a resistência ideológica de islamistas extremistas. Inevitável também a interferência dos talebã paquistaneses no Afeganistão, do regime iraniano no Iraque, e de novos ramos de al-Qaeda na Líbia para sabotar os projetos modernizadores trazidos por intervenções ocidentais. Os EUA se defrontam com sociedades cuja complexidade não é só "made in USA". Porém, nossa tarefa aqui não é um post-mortem detalhado para atribuir responsabilidades, mas uma analise das consequências e do novo quadro geopolítico que estas têm produzido. Ao analisar o quadro atual, é inegável constatar uma deplorável deterioração: situação política e militar crítica no Afeganistão, ameaça de desestabilização e de guerra civil no Iraque, fragmentação na Líbia, repressão no Egito, recrudescimento de al-Qaeda, crescentes tensões étnicas e comunitárias sob pano de fundo religioso na África Central e Ocidental, e na Ásia Meridional do Paquistão até a Indonésia... Devemos concluir que as intervenções não alcançaram seus objetivos. Um investimento gigantesco de capital político, meios econômicos, e vidas humanas foi usado para conseguir um resultado lastimável. 0 desapontamento e a reviravolta antiintervencionista que se seguiu não podem nos surpreender.

Resumindo: o intervencionismo humanitário do pós-Guerra Fria foi destruído pelo islamismo radical. O terrorismo islamista provocou a "guerra contra o terror", levando a uma virada intervencionista para desenraizar não apenas grupelhos jihadistas

\footnotetext{
17 A situação política e de direitos humanos é também deplorável em outros Estados árabes, p.ex. no Barein, cujo monarca absoluto e sunita ferozmente reprimiu o movimento democrático da maioria xiita, com o apoio de uma intervenção militar saudita e com inegável conivência estadunidense, motivada sem duvida por motivos estratégicos (presença da marinha EUA e proximidade com o Irã). No entanto o peso da pequena ilha petrolífera é muito menor do que o sírio.
} 
como também transformar e integrar as "sociedades doentes" que os criam. ${ }^{18}$ Estamos em meio a um colapso inédito do poder e da influencia dos EUA e do ocidente em geral, no mundo muçulmano. Não só no Afeganistão e no Iraque, como também no Paquistão, Turquia, Egito, Iêmen, e Jordânia, o antiamericanismo chegou a patamares jamais vistos. ${ }^{19} 0$ fracasso das intervenções ocidentais iniciados há uma década com grande fôlego, é boa notícia tanto para as jihadistas quanto para uma variedade de forças nacionalistas e autocráticas. A guerra contra o terror foi travada de forma tão inapropriada que intensificou uma reviravolta antiocidental agressiva. 0 resultado: os Estados ocidentais gostariam de manter as mãos "limpas", mas não podem se dar ao luxo de não reagir, apesar de não disporem mais do espaço político (doméstico e internacional) para reagir. Estão presos entre dois cenários, um menos atraente que o outro.

O efeito combinado de intervenções humanitárias, anti-proliferação e antiterrorismo tem sido o aumento de uma atitude anti-intervencionista global e uma reviravolta isolacionista e antiocidental. Este resultado é duplamente lamentável: em primeiro lugar, porque uma parte das intervenções foi inicialmente justificável e necessária; em segundo, porque muitos fatores que causaram o fracasso, e a desmoralização poderiam ter sido evitados.

Estamos presos entre duas reivindicações universalistas que se excluem: a uma ordem que refere, em última instância, ao projeto iluminista de critica racionalista e de emancipação da cidadania opõe-se um projeto islamista radical não menos universalista, que refere à revelação divina, e que pede a primazia da fé acima da razão, e da submissão a Deus acima da autodeterminação. Ambos projetos tem uma forte lógica interna e também importantes contradições internas, e o resultado de seu embate está ainda em aberto. 0 que é possível dizer é que há pouco mais de uma geração, poucos

\footnotetext{
${ }^{18}$ Contra a posição de relativismo cultural, cf. p.ex. Robert B. Edgerton, Sick societies: Challenging the myth of primitive harmony. New York: The Free Press, 1992.

19 Glenn Greenwald, "US more unpopular in the Arab world than under Bush". http://www.salon.com/2011/07/13/arabs/; Julian Borger and Tom Clark, "Widespread distrust of US extends beyond Middle East, poll shows". In: The Guardian, Tuesday 11 September 2012 http://www.theguardian.com/world/2012/sep/11/distrust-us-middle-east-poll; Pew Global Attitudes Project, 18 July 2013, "America's Global Image Remains More Positive than China's". Apesar de seu título otimista, providencia estatísticas gravíssimas do ponto de vista do soft power dos EUA no mundo muçulmano: http://www.pewglobal.org/2013/07/18/americas-global-image-remains-more-positivethan-chinas/; cf. também Arab American Institute, "Arab Attitudes: 2011" http://www.aaiusa.org/reports/arab-attitudes-2011.
} 
previam a expansão atual do islamismo ou o recente desnorteamento das democracias. Este último é espertamente explorado por lideranças autocráticas de potencias tais como a Rússia e a China - ainda que estas não possuam nenhuma alternativa ideológica, e possam também ser ameaçadas pelos islamistas.

A médio prazo - e ainda estamos neste prazo - o efeito das intervenções passadas, bem intencionadas mas mal executadas, tem estimulado enormemente um antiamericanismo já pré-existente no mundo muçulmano, pretenso beneficiário das intromissões ocidentais. Este animus também cresceu na Europa, América Latina e até entre muitos norte-americanos. Nos próprios EUA vigora atualmente uma atmosfera de cansaço de guerras. Hoje qualquer intervenção militar é considerada automaticamente como injusta e indevida.

O resultado é uma discrepância entre uma percepção de um EUA ávido de bombardear e roubar ao redor do mundo, e a realidade de um clima antiintervencionista que permeia os próprios EUA. Obama construiu sua presidência sobre a rejeição ao uso da força militar. A ideologia mais popular enfatiza que "já temos bastante problemas em casa, melhor concentrarmo-nos neles". A relutância contra aventuras estrangeiras junta-se facilmente ao protecionismo cultural que reluta à "invasão" de imigrantes culturalmente diferentes e/ou de "valores não americanos". No entanto a demanda para fechar as fronteiras (o barco está cheio) não é especifica dos EUA: tem seus paralelos na crescente xenofobia europeia, na homofobia russa, no antiamericanismo latino-americano e, nitidamente, na resistência à importação de idéias e praticas ocidentais "não islâmicas" dentro do mundo muçulmano.

0 isolacionismo cultural atual lembra os anos 30, época de crise econômica mundial e a fraca e covarde resistência das democracias ocidentais à emergência das ditaduras fascistas. ${ }^{20}$

$\mathrm{Na}$ época a impotência internacional era determinada pela isenção voluntaria dos EUA pós-Primeira Guerra e pelo anticomunismo cego ao perigo maior dos fascismos. Isto levou à Segunda Guerra. A lição dessa analogia com o período entre-guerras não é

\footnotetext{
20 Uma interessante e necessária discussão abarcaria o hipotético paralelo da situação hodierna na Europa com os anos 30. Nos últimos anos, vários partidos da direita eurofóbica e xenófoba têm chegado a patamares de $15 \%$ ou mais do eleitorado na França, Holanda, Áustria, Itália etc. A despeito de certas semelhanças desconcertantes, existem porém diferenças importantes. A maioria dos movimentos atuais da direita protecionista cultural abraçam a democracia; e a maioria não defende a perseguição e/ou eliminação das minorias (muçulmanas, no caso) mas sua assimilação forçada, e um fim a futuras imigrações. Grupos autenticamente neofascistas existem mas são muito menores.
} 
que os EUA deveriam novamente exercer o papel de policia do mundo (de fato, a maioria dos norte-americanos recusaria tal papel). Mas, tampouco significa que o mundo hodierno pode dispensar policiais. E a força "policial" necessária para enfrentar as crises das relações internacionais atuais, para funcionar bem, precisa ser mais eficiente do que nossos marronzinhos...

\section{A crise síria dentro da perene importância mundial do Oriente Médio}

0 prisma de "imperialismo contra resistência antiimperialista" não é adequado para entender as múltiplas crises médio-orientais atuais: Israel-Palestina, Iraque, Irã, Egito, Afeganistão e Paquistão. A tentação para analisar este caótico mundo através de um único fator responsável por tudo é, porém, compreensível, pois o Oriente Médio sempre foi e continua sendo um ímã de influencias externas múltiplas e encruzilhadas, e seu impacto sobre o resto do planeta é impar. Essa desproporcional projeção do Oriente Médio, das influencias que ele recebe de, e projeta para, outras regiões, se deve a três fatores estruturais: estratégico, econômico, e cultural.

1. Estratégia: sua posição geográfica torna o Oriente Médio uma região que qualquer liderança política - dos impérios antigos e confederações tribais-nômades aos Estados modernos - que queira a expansão além do próprio continente fatalmente deve atravessar. A bacia mediterrânea/médio-oriental/Mar Vermelho é portanto historicamente caracterizada por tensões geopolíticas permanentes e impares: ela compartilha esta centralidade com apenas algumas poucas outras regiões, p.ex. a Indonésia e a zona caribenha. As incessantes invasões que essa área sofre desde sempre constituem apenas a expressão militar de sua importância geográfica.

2. Economia: A presença das maiores reservas petrolíferas torna o Oriente Médio o nó central de abastecimento energético do mundo industrializado. A partir do começo do século 20, o controle e a exploração dos campos petrolíferos por companhias ocidentais (as "Sete Irmãs") foi um fator significativo do interesse pelo Oriente Médio por parte de britânicos, franceses e outros. Hoje, contudo, os países exportadores de petróleo são os proprietários da sua riqueza mineral - e não menos dependentes dos consumidores do que estes dos produtores. Após algumas 
tentativas de frustrar a nacionalização dos recursos energéticos (p.ex. o golpe contra Mossadeq no Irã em 1954), o mundo industrial se acomodou bastante bem com o controle do subsolo pelos Estados da região (enquanto os EUA se tornaram menos dependentes). Além disso, a renda petrolífera fácil e abundante permitiu ao mundo árabe e ao Irã a consolidação de autocracias com frouxa ligação orgânica com seus súditos - uma situação que a Primavera Árabe veio desafiar.

3. Cultura: 0 Oriente Médio é desde a antiguidade o epicentro ideológico do mundo. É berço das três grandes religiões monoteístas, que hoje compartilham dois terços da humanidade, tendo deixado ali um rastro de lugares sagrados e contestados. Atualmente é também o centro do islamismo (fundamentalismo islâmico), a única grande ideologia remanescente a rejeitar e desafiar a modernidade, se por modernidade entendemos o "pacote" constituído por capitalismo, democracia liberal, e direitos humanos individuais - combinação que antes já derrotara os sistemas rivais fascista e comunista. ${ }^{21} \mathrm{O}$ islamismo não deve se confundir com o islã enquanto religião. Apesar de um certo desconforto, a maioria dos muçulmanos no mundo tende a aceitar a modernidade. 0 islamismo, por outro lado, rejeita esta opção e instrumentaliza os meios da ciência e tecnologia modernas para combater os valores da modernidade. Suas vertentes mais radicais se expressam num jihadismo transnacional de cunho terrorista. Jihadistas atacam também alvos fora da região da Nigéria às Filipinas, dos uigures chineses até os chechênos em Moscou, indo de Toulouse a Boston. Contudo, o Oriente Médio permanece seu centro.

É, portanto, neste Oriente Médio que as expressões mais perigosas da intolerância religiosa e étnica se mesclam com uma série de crises pontuais mas interligadas. Entre elas, nenhuma é mais urgente do que a Síria. Desde 2011 esta deslizou para uma guerra civil que agora arrisca se expandirem toda a região. Como veremos na Parte II, a crise síria concentra todas as tragédias da Primavera Árabe e coloca as maiores dificuldades para a comunidade internacional.

Vimos nesta Parte I como se desenvolveu uma mescla associativa simbólica, embora incorreta, entre imperialismo e intervenção; como as pré-condições para uma mais justa ordem internacional que se esboçaram no imediato pós-guerra fria foram desafiadas pelo islamismo radical, única ideologia sobrevivente capaz de contestar o modelo da democracia liberal; como o 9/11 se tornou a alavanca de um novo 
intervencionismo; e como os desapontamentos com as novas intervenções produziram no ocidente o clima atual de anti intervencionismo - exatamente no momento quando a Primavera Árabe causou a necessidade de intervenções solidarias com os movimentos democráticos.

Porque esta participação internacional deixou de acontecer, quais os riscos acarretados pela isenção da comunidade internacional, e como ela poderia operar de maneira mais construtiva, na teoria - dada uma mais favorável conjuntura - tais são as perguntas que nortearão a segunda parte de nossa análise. 